\title{
Brátt andnauðarheilkenni á gjörgæsludeildum Landspítala 2004-2008
}

Pórður Skúli Gunnarsson ${ }^{1}$ læknir, Kristinn Sigvaldason² læknir, Kristbjörn I. Reynisson ${ }^{3}$ sérfræðingur í mynd- og geislagreiningu, Alma D. Möller² læknir

\section{ÁGRIP}

Tilgangur: Að kanna nýgengi, orsakir, dánarhlutfall og öndunarvélameðferð sjúklinga með brátt andnauðarheilkenni á gjörgæsludeildum Landspítala á fimm ára tímabili og bera saman við eldri íslenska rannsókn. Efniviður og aðferðir: Afturskyggn rannsókn par sem farið var yfir allar innlagnir á gjörgæsludeildir Landspítala árin 2004-2008 og upplýsingum safnað um aldurs- og kynjadreifingu, orsakir, legutíma, gjörgæslumeðferð og afdrif peirra sjúklinga sem féllu undir alpjóðlega skilgreiningu á bráðu andnauðarheilkenni. Niðurstöður voru bornar saman við niðurstöður eldri rannsóknar fyrir tímabilið 1988-1997 til að kanna hvort breytingar hafi orðið á nýgengi og horfum sjúklinga.

Niðurstöður: Alls lögðust 6413 sjúklingar inn á gjörgæsludeildir Landspítala á tímabilinu. Af 224 sjúklingum með alvarlega öndunarbilun reyndust 120 sjúklingar vera með brátt andnauðarheilkenni. Meðalaldur var 55 ár,
$55 \%$ voru karlar og miơgildi legutíma á gjörgæsludeild var 13 dagar en miðgildi legutíma á sjúkrahúsi 24 dagar. Miðgildi daga frá áfalli að staðfestu bráđu andnauðarheilkenni var prír dagar. Nýgengi reyndist vera 7,9 tilfelli á 100.000 íbúa/ári. Alls létust 36 sjúklingar vegna heilkennisins, eða $30 \%$ sjúklinga.

Ályktun: Nokkur aukning virðist hafa orðið á nýgengi bráđs andnauðarheilkennis en dánarhlutfall hefur hins vegar lækkað̃ marktækt, eða úr 40\% i 30\%. Bættar horfur sjúklinga með brátt andnauðarheilkenni má sennilega rekja til framfara í gjörgæslumeðferð, svo sem notkunar á lungnaverndandi öndunarvélameðferð, hátiððniöndunarvél, grúfulegu og hjarta- og lungnavél.
Fyrirspurnir: Kristinn Sigvaldason, svæfingaog gjörgæsludeild Landspítala Fossvogi krisig@landspitali.is

Greinin barst 11. mars 2013, sampykkt til birtingar 16. september 2013.

\section{Inngangur}

Brátt andnauðarheilkenni (BAH, Acute Respiratory Distress Syndrome, ARDS) er eitt af erfiðustu vandamálum sem fengist er við á gjörgæsludeildum sjúkrahúsa. Heilkennið felur í sér bráða öndunarbilun með dreifðum íferðum í báðum lungum í kjölfar annars sjúkdóms, slyss eða skurðaðgerðar. Bráðu andnauðarheilkenni var fyrst lýst árið 1967 hjá hermönnum sem slösuðust alvarlega í Víetnamstríðinu. ${ }^{1}$ Ætla má að með framförum í læknisfræði og betri lifun alvarlega veikra eða slasaðra sjúklinga hafi læknar farið að fást við vandamál sem lítið voru pekkt áður líkt og BAH. Allt frá pví heilkenninu var fyrst lýst árið 1967 hafa nýgengistölur verið mjög á reiki vegna mismunandi skilgreininga og hafa rannsóknir sýnt tíðnitölur á bilinu 4,5-75 tilfelli á 100 púsund íbúa/ár. ${ }^{2,3}$ Pað var pví stórt framfaraskref pegar samkomulag náðist um alpjóðlega skilgreiningu á bráðu andnauðarheilkenni árið 1992, sem gerði fræðimönnum kleift að gera samræmdar rannsóknir á tíðni, orsökum og horfum sjúklinga. ${ }^{4}$ Skilgreind voru hugtökin bráður lungnaáverki (ALI, acute lung injury) og brátt andnauðarheilkenni (ARDS, sjá töflu I). Dánarhlutfall hefur verið hátt og bentu fyrstu rannsóknir fyrir um 20 árum til pess að dánarhlutfall sjúklinga væri á bilinu 64$70 \%{ }^{5,6}$ Á undanförnum tveimur áratugum virðist dánarhlutfall pó hafa lækkað og er líklegast milli 30 og 40\%. ${ }^{7-9}$ Pá sýndi íslensk rannsókn yfir tímabilið 19881997 að dánarhlutfall sjúklinga með brátt andnauðarheilkenni á íslenskum gjörgæsludeildum var $40 \% .^{10}$
Bættar horfur sjúklinga með brátt andnauðarheilkenni má sennilega rekja til framfara í öndunarvélameðferð svo og framfara í gjörgæslulækningum almennt. Rannsóknir hafa sýnt að ef stuðst er við svokallaða lungnaverndandi meðferð í öndunarvél par sem andrýmd er haldið lágri og prýstingsaukning í loftvegi takmörkuð er dánarhlutfall sjúklinga lægra. ${ }^{11-13}$ Sjúklingar með alvarlegt brátt andnauðarheilkenni sem svara ekki hefðbundinni öndunarvélameðferð eru í meira mæli settir í hátíðniöndunarvél (HFOV, high frequency oscillatory ventilation), í grúfulegu (prone position) eða tengdir við hjarta- og lungnavél (ECMO, extracorporeal membrane oxygenation) sem lokaúrræði.

Prátt fyrir alpjóðlega skilgreiningu á bráðu andnauðarheilkenni hafa verið birtar mismunandi niðurstöður um nýgengi og dánarhlutfall milli landa sem ef til vill má rekja til ólíkra pjóðfélagsaðstæðna og heilbrigðiskerfa og pví er erfitt að heimfæra slíkar niðurstöður til Íslands. Markmið pessarar rannsóknar var pví að kanna orsakir, öndunarvélameðferð, nýgengi og dánarhlutfall sjúklinga með brátt andnauðarheilkenni á gjörgæsludeildum Landspítala á árunum 2004-2008 og bera saman við sambærilega eldri rannsókn sem framkvæmd var yfir tímabilið 1988-1997. Niðurstöður gætu gefið vísbendingu um hvort nýgengi hafi breyst og hvort framfarir í gjörgæslumeðferð hafi skilað sér í bættum horfum sjúklinga með brátt andnauðarheilkenni hér á landi. 
Tafla I. Samanburður milli ára á rannsóknartímabilinu ásamt samanburði við eldri rannsókn sem gerð var á tímabilinu $1988-1997$.

\begin{tabular}{|c|c|c|c|c|c|c|c|c|}
\hline Ár & Fjöldi & Látnir & Dánarhlutfall & Aldur & APACHE II & LIS & $\mathrm{PaO}_{2} / \mathrm{FiO}_{2}$ & Tilfelli á 100 pús. íbúa/ári \\
\hline 2004 & 18 & 5 & $27,8 \%$ & 57,9 & 20,6 & 3,15 & 119,9 & 6,2 \\
\hline 2005 & 23 & 6 & $26,1 \%$ & 55,5 & 17,3 & 3,06 & 109,3 & 7,8 \\
\hline 2006 & 26 & 9 & $34,6 \%$ & 47,1 & 18,2 & 3,01 & 102,2 & 8,7 \\
\hline 2007 & 28 & 8 & $28,6 \%$ & 58,8 & 18,0 & 3,00 & 109,3 & 9,1 \\
\hline 2008 & 25 & 8 & $32,0 \%$ & 55,6 & 18,6 & 3,24 & 130,1 & 7,9 \\
\hline 1988-1997 & 155 & 62 & $40,0 \%$ & 52,3 & 15,0 & 3 & 92,9 & 5,9 \\
\hline
\end{tabular}

APACHE II = ástandsstigun, LIS = Lung Injury Scale, lungnaáverkakvarði, $\mathrm{PaO}_{2}=$ súrefnisstyrkur í blóði, $\mathrm{FiO}_{2}=$ hlutfall súrefnis í innöndunarlofti.

\section{Efniviður og aðferðir}

Rannsóknin var afturskyggn og náði til gjörgæsludeilda Landspítala í Fossvogi og við Hringbraut tímabilið 2004-2008. Báðar deildirnar sinna almennum gjörgæslulækningum en með nokkurri sérhæfingu pó. Gjörgæsludeild Landspítala við Hringbraut sinnir einkum sjúklingum frá brjóstholsskurðlækningadeild, almennri skurðlækningadeild, kvennadeild, hjartadeild, krabbameinslækningadeild, barnadeild og meltingar- og nýrnadeild. Gjörgæsludeild Landspítala í Fossvogi sinnir aðallega sjúklingum frá heila- og taugaskurðdeild, æðaskurðdeild, bæklunarskurðdeild, taugalækningadeild, smitsjúkdómadeild, lungnadeild og sjúklingum með fjöláverka. Að auki er rekin gjörgæsludeild á Fjórðungssjúkrahúsinu Akureyri en að mati lækna peirrar deildar hafði ekki verið um nein tilfelli af bráðu andnauðarheilkenni að ræða par á rannsóknartímabilinu og var pví ekki farið yfir innlagnir sjúklinga par.

Að fengnu sampykki vísindasiðanefndar Landspítala, Persónuverndar og framkvæmdastjóra lækninga á Landspítala var farið yfir gjörgæsluskýrslur og sjúkdómsgreiningar allra sjúklinga sem lögðust inn á gjörgæsludeildir Landspítala á tímabilinu. Sjúkraskýrslur sjúklinga sem höfðu átt við alvarlega öndunarbilun að stríða voru skoðaðar sérstaklega og kannað hvort ástand peirra gæti fallið undir alpjóðlega skilgreiningu á bráðu andnauðarheilkenni: hefðu bráðan öndunarfærasjúkdóm, dreifðar íferðir í

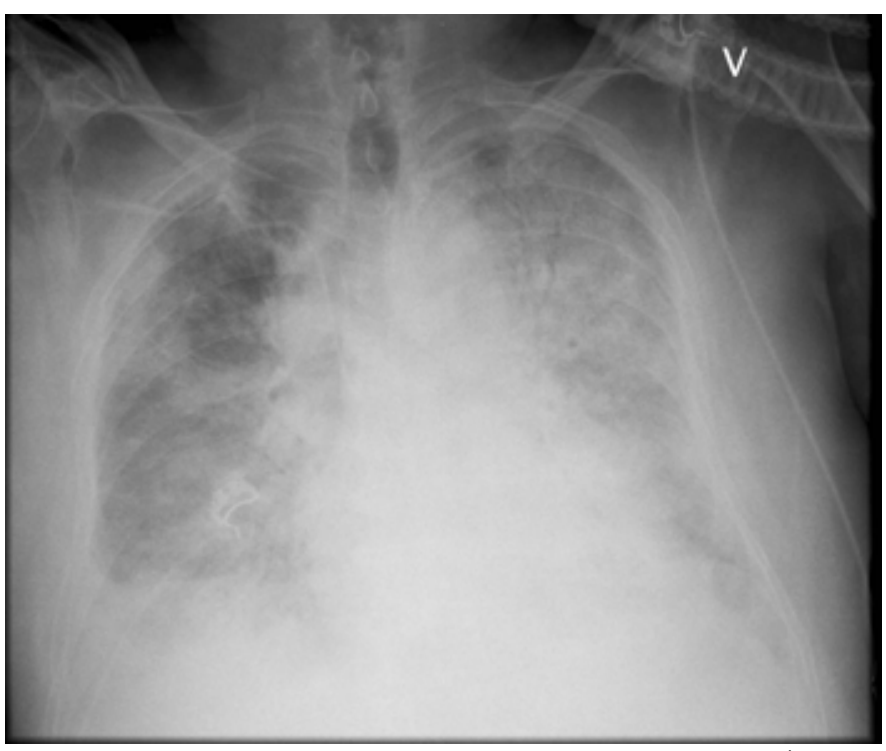

Mynd 1. Röntgenmynd af lungum sjúklings með brátt andnauðarheilkenni. Útbreiddar dreifðar íferđir sjást í bádum lungum. báðum lungum á röntgenmynd eða tölvusneiðmynd, hlutfall súrefnisstyrks í blóði á móti innönduðu súrefnishlutfalli $\left(\mathrm{PaO}_{2} / \mathrm{FiO}_{2}\right)$ lægra en 200 og fleygprýsting í lungnaslagæð (PCWP) lægri en 18 eða engin klínísk merki um hjartabilun. Sjúklingar voru útilokaðir ef einhverjum pessara skilyrða var ekki fullnægt.

Reiknað var lungnaáverkastig fyrir alla sjúklingana samkvæmt lungnaáverkakvarða Murray's (Lung Injury Scale, LIS) ${ }^{14}$ en samkvæmt honum eru gefin stig fyrir $\mathrm{PaO}_{2} / \mathrm{FiO}_{2}$ hlutfall, PEEP-stillingu á öndunarvél og hversu útbreiddar íferðir í lungum eru á lungnamynd. Sérfræðingur í mynd- og geislagreiningu fór yfir lungnamyndir allra sjúklinganna og mat hvort peir væru með brátt andnauðarheilkenni og hversu útbreiddar breytingar voru á lungnamynd samkvæmt lungnaáverkakvarða (LIS), mynd $1 .^{14}$

Safnað var upplýsingum um aldur, kyn, orsök, tíma frá áfalli að staðfestu heilkenni, legutíma á gjörgæsludeild, legutíma á sjúkrahúsi og afdrif sjúklinga. Skráð var notkun öndunarvéla, tímalengd peirrar meðferðar, stillingar, $\mathrm{PaO}_{2} / \mathrm{FiO}_{2}$ hlutfall og hvort notuð var sérhæfð meðferð, svo sem hátíðniöndunarvél, grúfulega eða hjartaog lungnavél (ECMO). Varðandi tíma frá áfalli að staðfestu heilkenni var stuðst við pann dag er gildi samræmdust skilgreiningu á bráðu andnauðarheilkenni $\left(\mathrm{PaO}_{2} / \mathrm{FiO}_{2}\right.$ hlutfall, ástand lungna samkvæmt lungnamynd). Ástand allra sjúklinga við innlögn var metið með APACHE II stigunarkerfi en samkvæmt pví eru gefin stig fyrir ástand sjúklinga fyrsta sólarhring dvalar á gjörgæsludeild, aldur, niðurstöður blóðmælinga og fyrri sjúkdóma.

Úrvinnsla fór fram með Excel töflureikni (Microsoft Corporation, Redmond, Washington) og tölfræðiforritinu IBM SPSS Statistics. Reiknuð voru miðgildi eða meðaltöl með staðalfrávikum og reiknað p-gildi með Wilcoxon rank test eða Students t-test. Upplýsingar um mannfjölda á Íslandi voru fengnar frá Hagstofu Íslands og pannig reiknað nýgengi heilkennisins á hverja 100.000 íbúa.

\section{Niðurstödur}

Á tímabilinu 2004-2008 voru alls 6413 sjúklingar lagðir inn á gjörgæsludeildir Landspítala, 3140 á Hringbraut og 3273 í Fossvogi. Karlar voru $60 \%$, meðalaldur var 58 ár, dánarhlutfall var 7,5\% og um helmingur innlagðra purfti meðferð í öndunarvél. Við nánari athugun reyndust 224 sjúklingar hafa alvarlega öndunarbilun og af peim reyndust 120 sjúklingar falla undir alpjóðlega skilgreiningu á bráđu andnauðarheilkenni, 54 konur og 66 karlar. Alls greindust 83 sjúklingar á gjörgæsludeild Landspítalans í Fossvogi en 37 á Landspítalanum við Hringbraut. Yfir allt tímabilið greindust pví 
Tafla II. Samanburður á peim sem létust og peim sem lifðu af brátt andnauðarheilkenni.

\begin{tabular}{lcccccc}
\hline Ástand e. $\mathrm{BAH}$ & $\mathrm{PaO}_{2} / \mathrm{FiO}_{2}$ & APACHE II & Aldur & Dagar í öndunarvél & Dagar á gjörgæsludeild & Dagar á sjúkrahúsi \\
\hline Lifðu & 120,0 & 17,4 & 50,0 & 14,0 & 18,0 & 38,0 \\
\hline Létust & 99,0 & 21,4 & 65,6 & 14,2 & 16,4 & 31,7 \\
\hline p-gildi & 0,007 & 0,0009 & 0,00001 & 0,961 & 0,570 \\
\hline
\end{tabular}

APACHE II = ástandsstigun, LIS = Lung Injury Scale, $\mathrm{PaO}_{2}=$ súrefnisstyrkur í blóði, $\mathrm{FiO}_{2}=$ hlutfall súrefnis í innöndunarlofti.

að meðaltali 24 sjúklingar með brátt andnauðarheilkenni á ári, eða 7,9 sjúklingar á hverja 100.000 íbúa/ári. Meðalaldur sjúklinga var 55 ár $( \pm 18,6)$. Tafla I sýnir samanburð á tíðni, dánarhlutfalli, aldri og APACHE II stigun á milli ára.

Alls létust 36 sjúklingar á gjörgæsludeildum Landspítalans af völdum pessa heilkennis, eða 30\%. Ef taldir eru með sjúklingar sem létust innan 30 daga frá útskrift af gjörgæsludeild var dánarhlutfall 37,5\% (45 sjúklingar) en 39,2\% ef miðað er við 90 daga frá útskrift af gjörgæsludeild (47 sjúklingar). Peir sem létust höfðu marktækt hærra APACHE II stig, lægra $\mathrm{PaO}_{2} / \mathrm{FiO}_{2}$ hlutfall og voru einnig marktækt eldri (sjá töflu II). Ekki var marktækur munur á fjölda daga í öndunarvél og legutíma á gjörgæsludeild hjá peim sem létust og peim sem lifðu. Miðgildi legutíma á gjörgæsludeild var 13 dagar (1-71 dagar) og miðgildi legutíma á sjúkrahúsi var 24 dagar (3-186 dagar). Alls voru 111 sjúklingar barkapræddir og meðhöndlaðir í öndunarvél en 9 sjúklingar purftu einungis öndunaraðstoð með ytri öndunarvél. Miðgildi daga í öndunarvél var 10 dagar (1-64 dagar). Í öllum tilfellum nema einu var stuðst við prýstingsstýrða öndunarvélameðferð. Notuð var hátíðniöndunarvél (high frequency oscillatory ventilation) í 16 tilfellum og var dánarhlutfall hjá peim sjúklingum 44\%. Grúfulega í 6-16 klukkustundir var notuð í 8 tilfellum og var dánarhlutfall 75\%. Í fjórum tilfellum purfti að nota hjarta- og lungnavél (ECMO) par sem hefðbundin öndunarvélameðferð eða hátíðniöndunarvél dugðu ekki til og var dánarhlutfall peirra sjúklinga 50\%. Tafla III sýnir yfirlit um öndunarvélameðferð.

Miðgildi daga frá áfalli að staðfestu bráðu andnauðarheilkenni var prír dagar (1-12 dagar). Heilkennið var komið fram hjá 44\% sjúklinga innan tveggja daga en hjá 78\% sjúklinga innan fjögurra daga. Dánarhlutfall var hæst ef heilkennið kom fram á áttunda degi eða síðar (57\%), mynd 2.

Orsakir bráðs andnauðarheilkennis eru sýndar í töflu IV. Algengustu orsakir reyndust vera lungnabólga, sýklasótt og ásvelging. Dánartíðni var mismunandi eftir orsökum. Orsakir voru flokkaðir eftir pví hvort pær voru innan lungna eða utan og

Tafla III. Öndunarvélameðferð.

\begin{tabular}{lcccc}
\hline & PC & HFOV & Ytri öndunarvél & VC \\
\hline Fjöldi & 94 & 16 & 9 & 1 \\
\hline Hlutfall & $78,3 \%$ & $13,3 \%$ & $7,5 \%$ & $0,8 \%$ \\
\hline Látnir & 27,0 & 7 & 2 & 0 \\
\hline Dánarhlutfall & $28,7 \%$ & $43,8 \%$ & $22,2 \%$ & $0,0 \%$ \\
\hline APACHE II & 18,4 & 18,7 & 19,0 & 13,0 \\
\hline PO $_{2} / \mathrm{FiO}_{2}$ & 116,5 & 91,3 & 120,3 & 142,9 \\
\hline PEEP & 10,5 & 13,4 & 7,0 & 8,0 \\
\hline APACHE & & & &
\end{tabular}

APACHE II = ástandsstigun, LIS = Lung Injury Scale, $\mathrm{PaO}_{2}=$ súrefnisstyrkur i blóði, $\mathrm{FiO}_{2}=$ hlutfall súrefnis í innöndunarlofti, PEEP = Positive End Expiratory Pressure,

$\mathrm{PC}=$ Pressure control (brýstingsstýrð). HFO $=$ High Frequency Oscillatory Ventilation (hátíðniöndunarvél), VC = Volume control (rúmmálsstýrð).



Mynd 2. Fjöldi tilfella og tími frá áfalli að brádu andnauðarheilkenni.

var skipting nokkuð jöfn par sem í 56 tilfellum mátti rekja orsökina til áfalls innan lungna en í 64 tilfellum utan lungna. Ekki var marktækur munur á dánarhlutfalli pessara hópa.

Fyrir alla sjúklinga var reiknað lungnaáverkastig (LIS) ${ }^{14}$ samkvæmt PEEP-stillingu á öndunarvél, $\mathrm{PaO}_{2} / \mathrm{FiO}_{2}$ hlutfalli og útbreiðslu íferða í lungum á lungnamynd. Meðaltal lungnaáverkastiga var 3,1. Samkvæmt lungnaáverkakvarða Murray's er um brátt andnauðarheilkenni að ræða ef lungnaáverkastig er $>2,5$ en 13 sjúklingar reyndust vera með lægra stig en 2,5 og lægsta gildið var 2,0. Lungnaáverkastig peirra sem létust var $3,3( \pm 0,36)$ að meðaltali en 3,0 $( \pm 0,47)$ hjá peim sem lifðu af, munurinn reyndist tölfræðilega marktækur $(\mathrm{p}<0,01)$.

\section{Umræða}

Brátt andnauðarheilkenni er alvarlegur sjúkdómur sem leggst á unga sem aldna og er meðferð umfangsmikil og krefjandi. Langflestir sjúklingar purfa meðferð í öndunarvél og dvelja tvær til prjár vikur á gjörgæsludeild og heildarsjúkrahúsvist er að meðaltali 33 dagar, pannig að meðferðin er kostnaðarsöm. Pessi rannsókn er önnur athugun á bráđu andnauðarheilkenni á Íslandi en sambærileg rannsókn var gerð fyrir tímabilið 1988-1997 og voru pær niðurstöður hafðar til hliðsjónar.

\section{Nýgengi}

Samkvæmt niðurstöðum eldri rannsóknarinnar var nýgengi 5,9 tilfelli/100.000 íbúa/ári' ${ }^{10}$ en hefur samkvæmt pessari rannsókn aukist í 7,9 tilfelli/100.000 íbúa/ár og er munurinn tölfræðilega marktækur $(\mathrm{p}=0,019)$. Í eldri rannsókninni voru teknir með sjúklingar á gjörgæsludeild Fjórðungssjúkrahússins á Akureyri og voru peir um 5\% af heildarfjölda. Í viðræðum við lækna peirrar deildar kom fram að ekki höfðu greinst tilfelli par á rannsóknartímabilinu 2004-2008 og var pví ekki farið yfir innlagnir par. Petta má telja 
Tafla IV. Orsakir bráđs andnauðarheilkennis.

\begin{tabular}{|c|c|c|c|c|c|c|c|c|}
\hline & Fjöldi & Látnir & Dánarhlutfall & APACHE II & Dagar í öndunarvél & Legudagar á gjörgæslu & $\mathrm{PO}_{2} / \mathrm{FiO}_{2}$ hlutfall & Aldur \\
\hline Lungnabólga & 41 & 13 & $31,7 \%$ & 18,5 & 14,2 & 17,1 & 113,2 & 56,9 \\
\hline Sýklasótt & 26 & 10 & $38,5 \%$ & 19,4 & 18,7 & 22,5 & 110,0 & 52,1 \\
\hline Ásvelging & 12 & 3 & $25,0 \%$ & 18,8 & 8,7 & 11,6 & 95,5 & 48,4 \\
\hline Lífhimnubólga & 7 & 3 & $42,9 \%$ & 15,2 & 16,3 & 19,0 & 123,6 & 58,3 \\
\hline Kviðarholsaðgerð & 5 & 1 & $20,0 \%$ & 18,2 & 12,0 & 15,6 & 127,0 & 65,0 \\
\hline Fjöláverkar & 4 & 1 & $25,0 \%$ & 16,8 & 16,8 & 20,8 & 126,9 & 61,3 \\
\hline Stoðkerfisaðgerð & 4 & 0 & $0,0 \%$ & 15,7 & 6,8 & 14,0 & 148,7 & 52,8 \\
\hline Ósæðaraðgerð & 3 & 2 & $66,7 \%$ & 12,3 & 13,0 & 19,0 & 94,2 & 65,0 \\
\hline Heilahimnubólga & 2 & 0 & $0,0 \%$ & 21,5 & 8,5 & 13,0 & 144,2 & 55,5 \\
\hline Briskirtilsbólga & 2 & 0 & $0,0 \%$ & 12,0 & 2,5 & 7,0 & 116,0 & 53,5 \\
\hline Hjartastopp & 2 & 0 & $0,0 \%$ & 22,0 & 4,5 & 7,0 & 145,0 & 27,5 \\
\hline Æðaaðgerð & 2 & 1 & $50,0 \%$ & 20,5 & 18,0 & 21,0 & 118,5 & 83,5 \\
\hline Lyfjaeitrun & 1 & 0 & $0,0 \%$ & 19,0 & 1,0 & 5,0 & 81,8 & 74,0 \\
\hline Brjóstholsaðgerð & 1 & 0 & $0,0 \%$ & 18,0 & 36,0 & 42,0 & 88,6 & 56,0 \\
\hline Bruni & 1 & 0 & $0,0 \%$ & 21,0 & 30,0 & 48,0 & 92,6 & 16,0 \\
\hline Drukknun & 1 & 1 & $100,0 \%$ & 30,0 & 9,0 & 9,0 & 140,0 & 11,0 \\
\hline Krabbameinsmeðferð & 1 & 0 & $0,0 \%$ & 16,0 & 7,0 & 8,0 & 181,0 & 58,0 \\
\hline Gallblöðrubólga & 1 & 0 & $0,0 \%$ & 14,0 & 5,0 & 8,0 & 110,0 & 57,0 \\
\hline Annað & 4 & 1 & $25,0 \%$ & 20 & 12,15 & 13,8 & 89,9 & 49 \\
\hline Alls & 120 & 36 & $30,0 \%$ & & & & & \\
\hline Orsök innan lungna & 56 & 17 & $30,4 \%$ & & & & & \\
\hline Orsök utan lungna & 64 & 19 & $29,7 \%$ & & & & & \\
\hline
\end{tabular}

APACHE II = ástandsstigun, LIS = Lung Injury Scale, $\mathrm{PaO}_{2}=$ súrefnisstyrkur í blóði, $\mathrm{FiO}_{2}=$ hlutfall súrefnis í innöndunarlofti.

galla par sem hugsanlega hefði verið hægt að greina einhverja sjúklinga með nánari athugun. Hins vegar er um fremur lítinn fjölda sjúklinga að ræða og prátt fyrir að einungis sé farið yfir sjúklinga Landspítalans hefur orðið marktæk fjölgun tilfella. Nýlegar rannsóknir erlendis frá gefa hins vegar vísbendingu um að tíðni sé jafnvel lækkandi síðastliðin ár. ${ }^{15}$ Ekki er ljóst af hverju nýgengi hefur aukist hér á landi, við greiningu tilfella var stuðst við sömu aðferð í báðum rannsóknum. Tíðnitölur hafa verið misjafnar síðan heilkenninu var fyrst lýst árið 1967, sennilega vegna breytilegra skilgreininga. Notast var við alpjóðlega AECC-skilgreiningu frá 1992 í pessari rannsókn sem og í eldri íslensku rannsókninni, og eru niðurstöður pví bornar saman við niðurstöður nýlegra erlendra rannsókna, sem stuðst hafa við sömu skilgreiningu. Samkvæmt niðurstöðum skoskrar rannsóknar frá 1999 reyndist nýgengi par vera 16 tilfelli á 100.000 íbúa/ári. ${ }^{16}$ Niðurstöður bandarískrar rannsóknar bentu til pess að nýgengi væri 58,7 tilfelli á 100.000 íbúa/ ári.7 Í samnorrænni rannsókn sem náði meðal annars til Íslands var kannað nýgengi framvirkt á fjögurra vikna tímabili árið 1999. Samkvæmt niðurstöðum peirrar rannsóknar er nýgengi 13,5 tilfelli á 100.000 íbúa/ári, miðað við íbúafjölda 15 ára og eldri. ${ }^{17}$ Pessar niðurstöður benda til pess að nýgengi bráðs andnauðarheilkennis sé nokkru lægra hér á landi, prátt fyrir aukningu frá árunum 19881997.

\section{Dánarhlutfall}

Af peim 120 sjúklingum sem féllu undir skilgreiningu á bráðu andnauðarheilkenni létust $36(30 \%)$ á gjörgæsludeild. Dánarhlutfall hefur pví lækkað marktækt frá árunum 1988-1997 pegar dánarhlutfallið var 40\% (p<0,01). $\mathrm{PaO}_{2} / \mathrm{FiO}_{2}$ hlutfall og APACHE II stig peirra sem létust voru marktækt lægri en peirra sem lifðu og greinilegt að horfur versna með hækkandi APACHE II stigi og lágu $\mathrm{PaO}_{2} / \mathrm{FiO}_{2}$. Samanburður við niðurstöður eldri rannsóknar sýnir að á tímabilinu 2004-2008 höfðu sjúklingar marktækt hærra APACHE II stig $(\mathrm{p}=0,003)$. Petta bendir til pess að ástand sjúklinganna sé alvarlegra en í fyrri rannsókn en prátt fyrir pað er árangur meðferðar betri. $\mathrm{PaO}_{2} / \mathrm{FiO}_{2}$ hlutfall er hins vegar marktækt hærra, sem bendir til pess að annaðhvort sé ástand lungna almennt betra eða að bætt öndunarvélameðferð sé að skila sér í betri loftskiptum sjúklinga, sem hlýtur að teljast líklegri skýring. Ætla má að aukin reynsla starfsfólks, betri öndunarvélameðferð og betri stuðningsmeðferð almennt stuðli einnig að betri lifun sjúklinganna. Niðurstöður rannsóknarinnar benda til pess að dánarhlutfall sjúklinga með brátt andnauðarheilkenni á gjörgæsludeildum á Íslandi sé ekki hátt miðað við niðurstöður erlendra rannsókna sem hafa sýnt um 30-50\% dánarhlutfall.,16,17 Árangur meðferðar virðist pví vera nokkuð góður hér á landi og sambærilegur við niðurstöður erlendra rannsókna.

\section{Orsakir}

Orsakir fyrir bráðu andnauðarheilkenni eru fjölmargar og voru á priðja tug samkvæmt niðurstöðum rannsóknarinnar. Algengustu orsakir reyndust vera lungnabólga, sýklasótt og ásvelging en stórar aðgerðir og fjöláverkar voru líka algengar orsakir.

Líklegt er að petta skýri mun á tíðni sjúkdómsins milli gjörgæsludeilda Landspítala. Fleiri greindust á gjörgæsludeild í Fossvogi en vegna sérhæfingar koma fleiri sjúklingar par til meðferðar 
til dæmis vegna vegna sýklasóttar og fjöláverka sem eru algengar orsakir bráðs andnauðarheilkennis. Á deildinni við Hringbraut eru fleiri sjúklingar með hjartabilun og kann pað að vinna gegn greiningu heilkennisins par sem greiningin er ekki sett ef til staðar eru klínísk teikn um hjartabilun. Talsverður breytileiki er á dánartíðni milli einstakra orsaka og má par nefna sem dæmi að dánartíðni sjúklinga með brátt andnauðarheilkenni eftir kviðarholsaðgerðir var $20 \%$, eftir fjöláverka $25 \%$ en $38 \%$ í kjölfar sýklasóttar (sjá töflu IV). Dánartíðni var mjög svipuð hvort sem orsökin var innan lungna eða utan og er pað í samræmi við niðurstöður erlendra rannsókna. ${ }^{18}$

\section{Meðferð}

Meðferð á bráðu andnauðarheilkenni byggist aðallega á stuðningsmeðferð par sem reynt er að koma sjúklingnum yfir hina alvarlegu öndunarbilun. Par skiptir öndunarvélameðferð mestu máli en á peirri meðferð hafa orðið töluverðar framfarir á seinni árum. Algengt var áður að hafa sjúklinga á rúmmálsstýrðri öndunarvélameðferð par sem andrýmd var um 10-15ml/kg. Slíkt getur haft í för með sér skaða á lungnablöðrum vegna ofpenslu lungna (volutrauma). Niðurstöður erlendrar rannsóknar benda til pess að lungnaverndandi öndunarvélameðferð skipti miklu máli í meðferð sjúklinga með brátt andnauðarheilkenni. ${ }^{11}$

Меð peirri meðferð er meðalloftvegaprýstingi haldið undir 30 $\mathrm{cm} \mathrm{H}_{2} \mathrm{O}$, andrýmd er haldið um $6 \mathrm{ml} / \mathrm{kg}$, beitt er hæfilegu PEEP (Positive End Expiratory Pressure) og reynt að halda styrk súrefnis í innöndunarlofti undir $60 \%$.

Samkvæmt niðurstöðum eldri íslensku rannsóknarinnar var í byrjun tímabils stuðst við rúmmálsstýrða meðferð í öndunarvél en á síðari hluta tímabils meira notast við prýstingsstýrða meðferð. ${ }^{10}$ Dánarhlutfall peirra sem fengu rúmmálstýrða meðferð var hærra. Samkvæmt niðurstöðum pessarar rannsóknar var í nær öllum tilfellum stuðst við prýstingsstýrða meðferð en hún er í eðli sínu meira lungnaverndandi en rúmmálsstýrð, par sem loftvega- prýstingstakmörk eru stillt fyrirfram. Hugsanlega gæti petta skýrt að hluta lækkun dánarhlutfalls milli rannsóknartímabila.

Ef ekki tekst að viðhalda viðunandi loftskiptum um lungu $\left(\mathrm{SaO}_{2}>85 \% ; \mathrm{pH}>7,20\right)$ með hefðbundinni öndunarvélameðferð með lungnaverndandi stillingum parf að huga að öðrum leiðum til að styðja við starfsemi lungna.,112 Pá er stundum beitt hátíðniöndunarvélum (high frequency oscillatory ventilation, HFOV) eða grúfulegu. Í erfiðustu tilfellum hafa sjúklingar verið tengdir við hjarta- og lungnavél (ECMO, extracorporeal membrane oxygenation) til að súrefnismetta blóðið utan líkamans og hvíla pannig lungun meðan bólga og bjúgur í lungum hjaðnar. Slík meðferð er ekki áhættulaus fyrir sjúklinginn auk pess sem hún er flókin og dýr. Pví parf að vanda vel valið á peim sjúklingum sem gangast undir slíka meðferð og um pað gilda ákveðnar verklagsreglur. Pær verklagsreglur sem gilda á Landspítala eru byggðar á niðurstöðum enskrar rannsóknar (CESAR) en samkvæmt henni næst ágætur árangur við ECMO-meðferð hjá völdum sjúklingum. ${ }^{19}$

Borið saman við niðurstöður eldri íslensku rannsóknarinnar var oftar notast við hátíðniöndunarvél (7,7\% á móti 13,3\%) og ECMO (0,6\% á móti 3,3\%) á síðara tímabilinu og gæti pað skýrt að einhverju leyti bættar horfur sjúklinga.

\section{Samantekt}

Tíðni bráðs andnauðarheilkennis hefur heldur aukist borið saman við eldri íslenska rannsókn. Að meðaltali greinast um 24 sjúklingar á ári með heilkennið, sem kemur fram um tveimur til premur dögum eftir áfall sem oftast er sýklasótt, lungnabólga, stór skurðaðgerð eða alvarlegt slys. Flestir sjúklingar purfa öndunarvélameðferð og um tveggja vikna legu á gjörgæsludeild. Horfur sjúklinga hafa batnað, sem líklega má pakka framförum í gjörgæslumeðferð. Aukin áhersla er lögð á lungnaverndandi öndunarvélameðferð og í erfiðum tilfellum grúfulegu, hátíðniöndunarvél eða hjarta- og lungnavél.

\section{Heimildir}

1. Ashbaugh DG, Bigelow DB, Petty TL, Levine BE Ashbaugh DG, Bigelow DB, Petty TL, Levine BE. Acute respiratory distress in adults. Lancet, Saturday 12 August 1967. Crit Care Resusc 2005; 7: 60-1.

2. Webster NR, Cohen AT, Nunn JF. Adult respiratory distress syndrome--how many cases in the UK? Anaesthesia 1988; 43: 923-6.

3. National Heart and Lung Institutes. Respiratory Diseases. Task force report on problems, research approaches, needs. Washington DC: US Goverment printing Office. DHEW publication 1972: 167-80.

4. Bernard GR, Artigas A, Brigham KL, Carlet J, Falke K, et al. The American-European Consensus Conference on ARDS. Definitions, mechanisms, relevant outcomes, and clinical trial coordination. Am J Respir Crit Care Med 1994; 149: 818-24.

5. Fowler AA, Hamman RF, Good JT, Benson KN, Baird M, Eberle DJ, et al. Adult respiratory distress syndrome: risk with common predispositions. Ann Intern Med 1983; 98: 593-7.

6. Villar J, Slutsky AS. The incidence of the adult respiratory distress syndrome. Am Rev Respir Dis 1989; 140: 814-6.

7. Rubenfeld GD, Caldwell E, Peabody E, Weaver J, Martin DP, Neff M, et al. Incidence and outcomes of acute lung injury. N Engl J Med 2005; 353: 1685-93.
8. Milberg JA, Davis DR, Steinberg KP, Hudson LD. Improved survival of patients with acute respiratory distress syndrome (ARDS): 1983-1993. JAMA 1995; 273: 306-9.

9. Jardin F, Fellahi JL, Beauchet A, Vieillard-Baron A, Loubieres Y, Page B. Improved prognosis of acute respiratory distress syndrome 15 years on. Intensive Care Med 1999; 25: 936-41.

10. Sigvaldason K, Pormar K, Bergmann JB, Reynisson K, Magnúsdóttir H, Stefánsson PS, et al. Brátt andnauðarheilkenni (ards) á giörgæsludeildum á Íslandi 1988-1997. Læknablaðið 2006; 92: 201-7.

11. Ventilation with lower tidal volumes as compared with traditional tidal volumes for acute lung injury and the acute respiratory distress syndrome. The Acute Respiratory Distress Syndrome Network. N Engl J Med 2000; 342: 1301-8

12. Verbrugge SJ, Lachmann B, Kesecioglu J. Lung protective ventilatory strategies to clinical application. Clin Physical Funct Imaging 2007; 27: 67-90.

13. Ramnath VR, Hess DR, Thompson BT. Conventional mechanical ventilation in acute lung injury and acute respiratory distress syndrome. Clin Chest Med 2006; 27: 601-13; abstract viii.
14. Murray JF, Matthay MA, Luce JM, Flick MR. An expanded definition of the adult respiratory distress syndrome. Am Rev Respir Dis 1988; 138: 720-3.

15. Li G. Eight year trend of Acute respiratory distress syndrome. Am J Respir Crit Care Med 2011; 183: 59-66.

16. Hughes M, MacKirdy FN, Ross J, Norrie J, Grant IS. Acute respiratory distress syndrome: an audit of incidence and outcome in Scottish intensive care units. Anaesthesia 2003; 58: 838-45.

17. Luhr OR, Antonsen K, Karlsson M, Aardal S, Thorsteinsson A, Frostell CG, et al. Incidence and mortality after acute respiratory failure and acute respiratory distress syndrome in Sweden, Denmark, and Iceland. The ARF Study Group. Am J Respir Crit Care Med 1999; 159: 1849-61.

18. Agarwal R, Srinivas R, Nath A, Jindal SK. Is the mortality higher in the pulmonary vs the extrapulmonary ARDS? A meta analysis. Chest 2008; 133: 1463-73.

19. Peek GJ, Clemens F, Elbourne D, Firmin R, Hardy P, Hibbert $\mathrm{C}$, et al. CESAR: conventional ventilatory support vs extracorporeal membrane oxygenation for severe adult respiratory failure. BMC Health Serv Res 2006; 6: 163. 


\section{ENGLISH SUMMARY}

\section{The incidence and mortality of ARDS at Landspítali - The National University Hospital of Iceland 2004-2008}

Gunnarsson ThS', Sigvaldason $\mathrm{K}^{2}$, Reynisson $\mathrm{Kl}^{3}$, Möller $\mathrm{AD}^{2}$

Objective: A retrospective study of the incidence, causes, mortality and treatment of patients with ARDS at Landspítali The National University

Landspítali during the study period and 120 patients were found to have Hospital of Iceland during the five year period 2004-2008 and comparing the results with an earlier study for the period 1988-1997.

Materials and methods: All ICU admissions during the period 2004-

2008 were reviewed, selecting patients according to the American-European consensus criteria for ARDS. Data were collected on age, gender, causes, length of stay, ventilator treatment and survival. ARDS giving an incidence of 7,9/100.000 inhabitants. Average age was 55 years, $55 \%$ were males, length of stay was 13 days and hospital stay 24 days. ICU mortality was $30 \%$ and 90 day mortality was $39 \%$.

Conclusion: The incidence of ARDS seems to have increased somewhat during the period 1988-1997. Mortality has decreased significantly probably due to improvements in intensive care treatment, especially ventilator treament with the use of lung protective ventilation, high frequency oscillation, prone position and ECMO.

Key words: ARDS, ARDS incidence, lung protective ventilation, respiratory failure.

Correspondence: Kristinn Sigvaldason, krisig@landspitali.is

${ }^{1}$ University of Iceland, Department of Medicine, ${ }^{2}$ Department of Anaesthesia and Intensive Care, ${ }^{3}$ Department of Radiology, Landspitali The National University Hospital, Reykjavik, Iceland. 